\title{
PENGARUH KEBIJAKAN POLITIK TERHADAP KEPATUHAN PHYSICAL DISTANCING MENCEGAH PENYEBARAN COVID-19
}

\section{EFFECT OF POLITICAL POLICY ON PHYSICAL DISTANCING COMPLIANCE PREVENTING THE SPREAD OF COVID-19}

\section{Aquarin}

Universitas Muhammadiyah

Palangkaraya

-Indonesia

email:

aquariniedward@gmail.com

\begin{abstract}
Abstrak
Physical distancing mengurangi risiko transmisi dan memperlambat penyebaran COVID19. Pemerintah lokal dan regional di banyak negara di dunia telah mengeluarkan kebijakan karantina untuk menerapkan physical distancing. Artikel ini mencoba menganalisis pengaruh kebijakan politik terhadap kepatuhan physical distancing mencegah penyebaran COVID-19 dengan menggunakan studi literatur. Hasil studi menunjukkan bahwa kepatuhan terhadap kebijakan ini tidak merata dan dapat dipengaruhi oleh keyakinan terhadap kebijakan politik pemerintah. Langkah-langkah physical distancing, yang dapat memperlambat penyebaran penyakit menular, dapat memungkinkan waktu sistem perawatan kesehatan untuk berkembang dan bersiap menanggapi COVID-19. Physical distancing sukarela yang substansial dan memberikan beberapa bukti bahwa langkahlangkah wajib dipatuhi dan juga efektif dalam mengurangi frekuensi individu untuk keluar rumah. Physical distancing sukarela dimoderatori oleh keberpihakan dan konsumsi media dengan cara yang meningkatkan pentingnya komunikasi yang jujur, jelas, dan konsisten oleh para pemimpin politik. Hasil ini konsisten ketika mempelajari bagaimana kebijakan politik dapat mempengaruhi kepatuhan physical distancing seluruh negara saat pemberlakuan lockdown. Temuan kami menyarankan agar pemimpin politik merancang strategi kreatif dan inovatif untuk mengkomunikasikan kebijakan untuk kesehatan masyarakat dan pesan tentang risiko yang terkait dengan COVID-19 cenderung lebih efektif untuk meningkatkan kepatuhan masyarakat terhadap physical distancing.
\end{abstract}

Kata kunci : kebijakan politik, physicall distancing, COVID-19.

\begin{abstract}
Physical distancing reduces the risk of transmission and slows the spread of COVID-19. Local and regional governments in many countries in the world have issued quarantine policies to implement physical distancing. This article tries to analyze the effect of political policy on physical distancing compliance to prevent the spread of COVID-19 by using literature studies. The study results show that adherence to this policy is uneven and can be influenced by beliefs in government political policy. Physical distancing measures, which can slow the spread of infectious diseases, can allow time for the health care system to develop and prepare to respond to COVID-19. Voluntary physical distancing is substantial and provides some evidence that measures must be complied with and are also effective in reducing the frequency of individuals leaving the house. Voluntary physical distancing is moderated by media alignment and consumption in ways that increase the importance of honest, clear, and consistent communication by political leaders. These results are consistent when studying how political policy can affect the compliance of physical distancing across countries during lockdown. Our findings suggest that political leaders design creative and innovative strategies to communicate policies for public health and messages about risks associated with COVID-19 tend to be more effective at increasing public compliance with physical distancing.
\end{abstract}

political policy, physicall distancing, COVID-19.

(c) (1) 2020 The Authors. Published by Institute for Re
is Open Access article under the CC-BY-SA Licen
DOl: https://doi.org//0.33084/anterior.vl8i2.456.
PENDAHULUAN
Pandemi Covid-I9 mengancam akan
membanjiri sistem perawatan kesehatan untuk
mencegah di lakukan langkah-langkah jarak sosial
untuk mengurangi penularan virus (Lipsitch et al, 2020).
Upaya-upaya menjauhkan sosial ini, baik melalui

persuasi atau paksaan, bergantung pada masyarakat untuk menerima kebutuhan untuk secara fisik terisolasi satu sama lain. Kesalahan informasi terus-menerus disebarkan oleh media sosial, outlet berita, dan pemimpin politik, tidak jelas apakah upaya seperti itu bisa berhasil, atau jika identitas kurir dan penerima 
berpengaruh. Survei dan jajak pendapat yang dilakukan sejak awal Maret agak menggembirakan dengan peningkatan mencuci tangan dan langkah-langkah lainnya. Namun, ada perbedaan besar dengan keberpihakan, menunjukkan bahwa efektivitas langkahlangkah jarak sosial mungkin tergantung pada identitas partisan (Andersen, 2020).

Menanggapi pandemi COVID-19, di samping langkah-langkah kesehatan masyarakat yang lebih rutin, banyak negara telah menerapkan "lockdown" - menutup perbatasan, membatasi perjalanan internasional, dan menempatkan batasan berat pada pergerakan individu dan pertemuan kelompok. Walaupun lockdown mungkin merupakan alat penting untuk membatasi penularan, namun lockdown berpotensi menimbulkan biaya besar berkaitan dengan dampak ekonomi, konsekuensi kesehatan mental, dan peningkatan morbiditas dan mortalitas dari penyakit non-COVID19 (Bausch, 2020).

Karantina, lockdown atau aturan physical distancing mencerminkan perubahan yang cepat dan substansial dalam kehidupan sehari-hari. Lelucon dan video lucu dapat membantu orang untuk menerima perubahan dalam hidup mereka. Perubahan tersebut menghasilkan banyak sumber ketidakpastian dan stres, yang sebagian humor dapat meringankan, setidaknya dalam jangka pendek (Martin \& Ford, 2018).

skenario terburuk, lockdown dapat menyebabkan kerusuhan sipil, seperti yang terlihat di Nigeria, negara di mana $48 \%$ populasi (96 juta orang) hidup dalam kemiskinan ekstrem. Meskipun ada pasokan makanan yang stabil di negara-negara kaya sumber daya, bahkan di sana, lockdown, terutama jika berkepanjangan, pada akhirnya dapat menyebabkan kerawanan pangan dan populasi yang gelisah, dengan potensi protes dan keresahan sipil, seperti yang barubaru ini terjadi. telah terlihat di Amerika Serikat. Pengenaan lockdown yang ketat di Yordania bertemu dengan kekacauan dan lebih dari seribu penahanan ketika akses ke makanan diancam, memaksa Raja Abdullah II untuk memanggil pasukan keamanan dan, setidaknya untuk sementara mengurangi batasan (Bausch, 2020).

Karena SARS-CoV-2 paling umum menyebar melalui tetesan dari mulut atau hidung, otoritas kesehatan masyarakat merekomendasikan kebersihan tangan secara teratur dan menyeluruh, etiket batuk dan bersin yang tepat, dan physical distancing yang aman dengan orang lain (Seres et al, 2020).

Physical distancing mengurangi risiko transmisi interpersonal (Anderson et al., 2020; Bai et al., 2020; Viner et al., 2020). Kebijakan pemerintah yang mengamanatkan physical distancing memperlambat penyebaran COVID-19 (Hsiang et al., 2020). Ketidakpatuhan lokal dengan pesanan tempat tinggal ini menciptakan risiko kesehatan masyarakat dan dapat menyebabkan penyebaran regional (Chen et al., 2020; Lewnard dan Lo, 2020). Memahami faktor tingkat lokal mana yang memengaruhi kepatuhan adalah perhatian kebijakan publik orde pertama (Briscese et al., 2020).

Artikel ini memberikan perkiraan tentang bagaimana tindakan pemerintah mempengaruhi perilaku masyarakat di beberapa dimensi, dan pada gilirannya itu sendiri dipengaruhi oleh keputusan yang dibuat oleh populasi pada umumnya. Dari perspektif kebijakan, memahami bagaimana masyarakat merespons tindakan pemerintah terhadap kebijakan physical distancing. COVID-19 telah menyebabkan krisis kesehatan yang belum pernah terjadi sebelumnya dan gangguan besar pada sistem ekonomi global di seluruh dunia.

Para pemimpin di banyak negara telah mengambil langkah-langkah untuk membatasi tingkat penularan untuk mengurangi tekanan pada sistem perawatan kesehatan dan mencegah kelebihan kematian. Sementara ketidakpastian epidemiologis tentang virus dan penyebarannya tetap ada (Anderson et al., 2020), penelitian tentang Cina dan Korea Selatan menunjukkan bahwa tindakan awal pemerintah dan kerja sama oleh penduduk dapat membendung penyebaran pandemi yang tidak terkendali (Kraemer et al., 2020 ; Wilder-Smith \& Freedman, 2020; Wu \& McGoogan, 2020).

Kebijakan yang diterapkan pemerintah guna mencegah penyebaran COVID-19 disebabkan tidak adanya vaksin, perawatan yang efektif, atau pengujian yang meluas, pencegahan dengan menerapkan tindakan mulai dari mencuci tangan hingga Physical diatancing, sangat penting untuk mengurangi kecepatan dan tingkat penyebaran virus (Kraemer, et al, 2020). Beberapa tindakan, seperti tinggal di rumah, secara khusus tunduk pada ketidakpatuhan, dengan kemungkinan konsekuensi yang mengerikan untuk upaya "meratakan kurva" infeksi baru. 
Intervensi physical distancing berusaha untuk mengurangi kontak yang relevan dengan penyebaran penyakit menular antar individu. Berbagai survei telah dilakukan untuk mengambil langkah-langkah physical distancing yang berbeda selama pandemi saat ini, tetapi ini belum secara eksplisit mengukur kontak antara orang-orang (Atchison et al, 2020)

Para pemimpin negara memainkan peran penting dalam membujuk masyarakat untuk secara sukarela mematuhimahal langkah-langkah pencegahan yang selama pandemi. Selain mengeluarkan perintah yang berfungsi untuk mengurangi kontak antara individu, komunikasi politisi tentang keparahan yang harus individu dihadapidengan penyakit yang menyebar dengan cepat dan tindakan pencegahan yang harus dibuat cenderung sangat berpengaruh ketika ada informasi yang terbatasdiberikan oleh pemerintah. tentang penyakit baru, seperti COVID-19. Pemahaman yang lebih baik tentang hubungan antara komunikasi politik dan sukarela individu adopsiatas tindakan pencegahan dengan demikian sangat penting untuk upaya berkelanjutan untuk membatasi penyebaran COVID-19 dan untuk meningkatkan kesehatan masyarakat secara lebih umum.

Mitigasi dan tekanan bertujuan untuk menurunkan permintaan layanan kesehatan maksimum dengan mengurangi tingkat penularan melalui intervensi non-farmasi, sementara pendekatan yang terakhir mengadopsi langkah-langkah yang sangat ketat untuk menekan prevalensi kasus baru menjadi nol (Ferguson et al, 2020). Sebagian besar peneliti berpendapat bahwa hanya campuran langkah-langkah penekan seperti isolasi rumah yang wajib dan kebijakan lockdown yang dapat berhasil dalam mengurangi penyebaran virus. Intervensi ini mungkin perlu dipertahankan selama beberapa tahun (Kissler et al., 2020) dan dilengkapi dengan penutupan sekolah dan bisnis (Ferguson et al., 2020; Hellewell et al., 2020). Namun, meskipun kebijakan lockdown sangat penting dalam memperlambat tingkat infeksi selama fase awal penyakit (Stoecklin et al., 2020; Wu et al., 2020; Xiao dan Torok, 2020; Zu et al., 2020),

Pemerintah di banyak negara telah mengadopsi langkah-langkah physical distancing untuk mengurangi dampak dari COVID-19 panik. Namun, tidak jelas sejauh mana langkah-langkah ini mengurangi jumlah kontak dan karenanya transmisi. Peran yang dimainkan polarisasi politik dalam menanggapi penyakit bukanlah hal baru, dengan respons terhadap HINI dan Covid19 mencerminkan perbedaan-perbedaan partisan. Sebagai contoh, sebagai tanggapan terhadap Flu Babi pada tahun 2009, terdapat perbedaan yang jelas antara pentingnya vaksinasi terhadap flu babi'dan dalam tingkat vaksinasi aktual. Pada saat yang sama, pengesahan pembersih tangan berbasis alkohol oleh Presiden Obama sudah cukup untuk mendorong penggunaan pembersih tangan berbasis alkohol di beberapa toko (Rothgerbe et al, 2020).

Banyak negara berupaya membatasi penyebaran COVID-19 dengan pendekatan yang berbeda (Tanne et al, 2020). Berbagai mitigasi strategi komunitas diterapkan, (Ebrahim et al, 2020). Beberapa penemuan medis baru-baru ini tidak secara luas dikomunikasikan kepada publik, dan pengetahuan dan sikap tentang infeksi tidak diukur secara rutin di masyarakat, sementara itu mungkin penting untuk mencegah epidemi gelombang kedua. Kurangnya pengetahuan yang dibagikan secara publik menjadi masalah tidak hanya dalam konteks meningkatnya kekhawatiran tentang berita palsu, (Ireton \& Posetti, 2018) tetapi juga dalam konteks ketidak percayaan terhadap lembaga-lembaga publik (Bikbov \& Bikbov, 2020) mempromosikan norma-norma perilaku individu dan mengkoordinasikan kerja sama masyarakat selama epidemi.

Kepatuhan warga terhadap tindakan dan kebijakan kesehatan dapat memiliki efek penting pada keadaan kesehatan masyarakat. Ini adalah kasus imunisasi massal melalui vaksin, misalnya. Karena physical distancing merupakan kunci dalam mencegah difusi COVID-19 yang cepat, pandemi ini memaparkan pentingnya ko-produksi' untuk kesehatan masyarakat di negara-negara demokrasi: kemanjuran dan efisiensi tindakan tergantung pada kepatuhan warga negara terhadapnya Temuan baru-baru ini mengkonfirmasi bahwa isyarat dan bujukan sumber dapat memiliki efek kuat pada sikap warga, dukungan untuk kebijakan publik (Mariani et al, 2020). Masyarakat cenderung mengikuti isyarat dari pemimpin yang membuat solusi atas kebijakan politik yang dibuat untuk menangani COVID-19,

\section{METODOLOGI}

Artikel ini menerapkan metode kualitatif dengan jenis studi literatur dari sejumlah artikel. Studi literatur dilaksanakan dengan melakukan pencarian terhadap berbagai 
sumber tertulis, baik berupa buku-buku, arsip, majalah, artikel, dan jurnal, atau dokumen-dokumen yang relevan dengan permasalahan yang dikaji. Sehingga informasi yang didapat dari studi kepustakaan ini dijadikan rujukan untuk memperkuat argumentasi-argumentasi yang ada.

\section{HASIL DAN PEMBAHASAN}

\section{Hasil dan Pembahasan}

\section{Physicl Distancing}

Physical distancing telah menjadi alat penting dalam mengurangi infeksi dan kematian selama pandemi sebelumnya dan tampaknya efektif terhadap Covid-19 di Cina. model Matematika juga menunjukkan bahwa langkah-langkah jarak sosial yang diberlakukan di Eropa dapat mencegah sebanyak 59000 kematian akibat Covid-19 hingga akhir Maret. Hasil penelitian menunjukkan bahwa tindakan jarak sosial wajib wajib dikaitkan dengan pengurangan kunjungan ke tempat-tempat di luar rumah di suatu daerah. Pesan tetap di rumah atau tempat berlindung yang paling ketat dikaitkan dengan penurunan 19,3 persen dalam kunjungan di luar rumah. Meskipun jumlah ini mungkin tampak kecil, ia harus ditafsirkan dalam konteks jarak sosial sukarela yang sudah ada sebelumnya. Sebagai contoh, urutan yang tinggal di rumah pertama mulai berlaku pada 17 Maret di San Francisco, saat pengurangan sukarela dalam jarak sosial telah mengakibatkan penurunan 40 persen dalam kunjungan dalam kota (Andersen, 2020).

Kesehatan publik dan tindakan sosial adalah tindakan atau tindakan oleh individu, institusi, komunitas, lokal dan pemerintah nasional dan badanbadan internasional memperlambat atau menghentikan penyebaran COVID-19. Langkah-langkah ini untuk mengurangi transmisi COVID-19 termasuk tindakan individu dan lingkungan, mendeteksi dan mengisolasi kasus, pelacakan kontak dan karantina, sosial dan physical distancing . Pengukuran termasuk untuk pertemuan massa, perjalanan internasional, vaksin dan perawatan. Sementara vaksin dan obat-obatan spesifik tidak tersedia untuk COVID-19, kesehatan publik dan pengukuran sosial bermain sangat penting dalam mengurangi jumlah individu yang terinfeksi dan mengurangi jumlah korban meninggal (WHO, 2020).

\section{Kebijakan Tentang Physical Distancing \\ Kebijakan yang diterapkan oleh pemerintah}

dapat mempengaruhi kepatuhan masyarakat terhadap pemberlakuan physical distancing. Evaluasi posisi kebijakan didorong dari atas ke bawah dengan elite partai memberi sinyal pandangan yang sesuai dan individu mengikuti petunjuk yang sesuai dengan ideologi sebelumnya. Penelitian yang konsisten dengan teori kognisi budaya menunjukkan bahwa individu lebih dibujuk oleh para ahli kebijakan yang dianggap memiliki nilai yang sama dengan nilai mereka sendiri. Berdasarkan konteks politik Amerika baru-baru ini, kami berpendapat bahwa pendapat tentang COVID-19 telah menjadi identitas penting sebagai penanda yang membedakan kaum liberal dari kaum konservatif; pandangan liberal menekankan ancaman yang ditimbulkan oleh virus dan urgensi dalam menahan penyebarannya, sementara pandangan konservatif menekankan reaksi berlebihan terhadap ancaman yang berlebihan. Begitu persepsi keparahan COVID-19 dikaitkan dengan identitas politik, individu mungkin sudah mulai memproses informasi selanjutnya melalui lensa ideologis, membuat objektivitas menjadi lebih sulit (Rothgerber et al, 2020).

Kebijakan sosial penting bagi manajemen krisis dan juga pemulihan: Sangat menggoda, tetapi salah, untuk berpikir bahwa kebijakan sosial dan ekonomi hanya masalah pemulihan. Ini juga masalah darurat tanggapan. Langkah-langkah kesehatan masyarakat yang relatif otoriter (seperti physical distancing atau shutdowns ekonomi sementara) tergantung pada kepatuhan masyarakat. Itulah yang terjadi bahkan dalam rezim otoriter. Kepatuhan tidak hanya menuntut hal-hal seperti komunikasi dan kepercayaan yang baik, tetapi juga ekonomi politik yang memungkinkan orang untuk tinggal di rumah tanpa kelaparan. Kebijakan sosial negara yang sudah ada sebelumnya serta yang ditetapkan secara spesifik untuk menanggapi tantangan COVID-19 akan membentuk tingkat kepatuhan terhadap tindakan kesehatan masyarakat serta kehidupan setelah pandemi (Greer et al, 2020).

Kepercayaan pada pemerintah adalah penentu penting kepatuhan warga negara terhadap kesehatan masyarakat kebijakan, terutama di masa krisis. Hubungan ini, jarang dipelajari dalam literatur, pantas perhatian khusus dalam konteks pandemi global saat ini. COVID-19 telah memaksa pemerintah untuk mengambil tindakan drastis di seluruh dunia. Kebijakan lockdown seringkali sangat membatasi dan harus 
menerima dukungan besar oleh populasi agar efisien (dukungan ini tidak dijamin dan tentu saja tidak homogen. Kepercayaan politik yang lebih tinggi dikaitkan dengan pengurangan yang lebih besar dalam mengikuti arahan yang tidak esensial implementasi kebijakan physical distancing pada bulan Maret 2020. Pengaruh ini ditafsirkan sebagai sebuah tingkat kepatuhan yang lebih tinggi terhadap arahan nasional di wilayah yang memiliki kepercayaan tinggi. Besarnya pengaruh kepercayaan pada efektivitas kebijakan yang ketat (Bargain \& Aminjonov, 2020).

\section{Keuntungan physical distancing untuk melawan COVID-19}

Keuntungan dari physical distancing yang presisi relatif terhadap banyak tindakan lain adalah dapat dikembangkan dengan biaya rendah dan disesuaikan dengan beragam pengaturan sosiokultural dan ekonomi, termasuk yang di mana kompleksitas atau biaya sosial untuk mempertahankan kuncian sangat tinggi. Pedoman dapat dikembangkan secara kolaboratif pada tingkat yang sangat lokal oleh para pemimpin lokal, bahkan berpotensi pada skala lingkungan. Di tempat-tempat di mana COVID-19 belum diperkenalkan atau di mana transmisi luas belum terjadi, implementasi physical distancing, bersama dengan langkah-langkah lain, bahkan dapat membantu menghindari perlunya tindakan lockdown. Pemerintah dalam menerapkan kebijakan dapat melkukan pendekatan dan melibatkan masyarakat sebagai mitra sentral dalam perjuangan melawan COVID-19, melawan pesan implisit "kami melawan mereka" dari pemerintah tentang lockdown. Meskipun keuntungan dari kontrol desentralisasi jelas, perhatian harus diberikan untuk menjaga terhadap individu dan masyarakat yang berusaha menerapkan kebijakan yang tidak berdasarkan bukti atau bahkan bertentangan dengan nasihat kesehatan masyarakat, dengan potensi dampak negatif, termasuk peningkatan Transmisi COVID-19, di komunitas mereka dan sekitarnya. Prinsip menjaga bukti berdasarkan pedoman, sejauh bukti ada, harus selalu dihormati (Bausch, 2020).

\section{Kepatuhan masyarakat menerapkan physical distancing untuk melawan COVID- 19 \\ Keberhasilan upaya mencegah penyebaran COVID-19 sangat tergantung pada tindakan yang}

diambil oleh individu yang diminta untuk secara sukarela patuh dengan langkah-langkah untuk mencegah penularan. Sangat penting pemimpin negara berupaya untuk mengkomunikasikan kebijakan physical distancing, tetapi juga bahwa preferensi partai politik memengaruhi respons individu terhadap kepatuhan physical distancing dan tinggal di rumah selama merebaknya coronavirus.

Meskipun cialis lebih suka istilah " physical distancing " untuk menekankan pemantauan yang ditingkatkan kebutuhan untuk interaksi sosial dan dukungan yang berkelanjutan, meskipun sumber daya keuangan, ini tentu akan kurang ekonomis tanpa interaksi fisik. Pedoman untuk physical distancing daripada pemberlakuan lockdown yang berkepanjangan. Di Inggris, langkah-langkah physical distancing menghindari pertemuan massa, dan menjaga jarak yang aman terkait dengan pengurangan $73 \%$ dalam jumlah harian dari orang lain untuk membatasi kemampuan sebaran. (Bausch, 2020).

Populasi yang menganggur, tertekan, tidak aktif secara ekonomi, dan terkepung dalam lingkungan yang teridentifikasi tidak sehat. Pemerintah diharapkan dapat membuat kebijakan politik untuk membantu masyarakat yeng terkena dampak. Untuk pencegahan penyebaran pandemi COVID-19, physical distancing adalah salah satu komponen penting dari solusi jangka panjang yang berkelanjutan yang sebanding dengan risiko namun tidak memiliki dampak yang tidak proporsional pada masyarakat dan ekonomi, memungkinkan sebagian kembali ke kegiatan normal, dengan komunitas sebagai mitra penting (Bausch, 2020).

Efek Aksi Masyarakat terhadap Aksi Pemerintah. Tindakan masyarakat independen memengaruhi probabilitas pemerintah negara untuk memperkenalkan kebijakan physical distancing dan lockdown. Individu berlatih melakuan physical distancing bahkan sebelum pengenaan tindakan penahanan, baik itu untuk meminimalkan risiko individu, untuk membatasi penularan dalam komunitas atau karena masyarakat mengantisipasi kebijakan physical distancing

Di bawah skenario ini, pemerintah dapat memperkenalkan langkah-langkah luas untuk menekan penyebaran pandemi dengan biaya politik yang cukup rendah, namun efek kesehatan tambahan dari kebijakan physical distancing akan relatif kecil. Biaya 
politik yang lebih rendah akan menyarankan lebih kuat aksi masyarakat yang independen memicu tindakan pemerintah yang lebih kuat; efek yang lebih kecil di kesehatan publik akan menyarankan sebaliknya. Sebaliknya, jika populasi menolak untuk mematuhinya secara memadai pemerintah akan memberlakukan kebijakan panggilan non-wajib karena penolakan untuk physical distancing (Brzezinski et al, 2020).

\section{Langkah-langkah Kebijakan Politik Mendukung Pencegahan COVID-19}

Sementara kepercayaan dan kepatuhan yang menurun dalam suatu negara sering terbukti memiliki dampak sosial-ekonomi yang besar, masyarakat juga dapat memiliki konsekuensi dramatis ketika kepatuhan diperlukan untuk kelangsungan hidup. Tindakan social distancing dan physical distancing bertujuan untuk memperlambat penyebaran penyakit dengan menghentikan rantai penularan COVID-19 I. Langkahlangkah physical distancing antara orang-orang (diminimal satu meter), dan kurangi kontak orangorang yang terinfeksi COVID-19, sambil mendorong dan mempertahankan sosial virtual koneksi dalam keluarga dan komunitas.

Langkah-langkah untuk masyarakat umum termasuk memperkenalkan pekerjaan yang pengaturan fleksibel seperti teleworking, pembelajaran jarak jauh, mengurangi dan menghindari crowding, penutupan fasilitas dan layanan yang tidak penting, tameng dan perlindungan untuk kelompok rentan, pembatasan pergerakan lokal atau nasional dan tinggal di rumah, dan mengoordinasikan layanan kesehatan dan jaringan layanan sosial untuk melindungi rumah sakit. Langkahlangkah ini digunakan bersama dengan tindakan perlindungan individu terhadap COVID-19 seperti sering mencuci tangan dan menutup mulut ketika batuk (WHO, 2020).

Semua tindakan kesehatan masyarakat untuk menghentikan penyebaran penyakit dapat diseimbangkan dengan strategi adaptif untuk mendorong ketahanan masyarakat dan koneksi sosial, melindungi pendapatan dan mengamankan pasokan makanan. Negara harus menyeimbangkan kemungkinan manfaat dan konsekuensi negatif dari setiap intervensi dan menerapkan strategi untuk mendorong keterlibatan masyarakat, mendapatkan kepercayaan dan membatasi kerugian sosial atau ekonomi. Ada banyak strategi yang dapat mendukung ketahanan masyarakat dan kesehatan mental, melindungi akses ke layanan penting, dan membatasi dampak ekonomi. Pengukuran stayat-home dimanan kebijakan ini dianggap perlu. Pengorganisasian situs kerja untuk memastikan physical distancing dapat dilakukan dengan tele-working dan tele-schooling, strategi berbeda konteks mendemonstrasikan inovasi dan penggunaan teknologi dalam mendukung keberlangsungan bisnis dan mempertahankan koneksi sosial dalam keluarga dan komunitas.

\section{KESIMPULAN}

Penyebaran COVID-19 telah membuat pemerintah lokal dan nasional di seluruh dunia berjuang untuk mengimplementasikan kebijakan yang bertujuan membatasi interaksi sosial sehingga meredam penyebaran virus, mengurangi tekanan pada sistem rumah sakit, dan menyelamatkan nyawa. Walaupun sifat drastis dari kebijakan physical distancing berpengaruh terhadap interaksi sosial masyarakat. Physical distancing mencerminkan kebjakan negara, wilayah, atau lokalitas, tetapi sebagian besar muncul dari upaya sukarela oleh individu. Hasil studi menunjukan bahwa tidak terjadi penolakan individu untuk mematuhi penerapan physical distancing, meski bukan dari pemimpin yang disukai oleh individu tersebut. Namun, kepatuhan dipengaruhi oleh kebijakan pemerintah memerikan solusi atas kebijakan physical distancing, seperti memberikan tunjangan langsung tunai, dan memberikan kelonggaran kepada masyarakat untuk tetap menjalankan bisnis dengan mematuhi protokol kesehatan guna mencegah penyebaran COVID-19. Penelitian berikutnya disarankan untuk menganalisis keberpihakan partai politik dan pemimpin negara kepada masyarakat dalam membuat kebijakan penanganan pasca COVID-19.

\section{REFERENSI}

Anderson, R.M., Heesterbeek, H., Klinkenberg, D. and Hollingsworth, T.D., 2020. How will country-based mitigation measures influence the course of the COVID-19 epidemic?. The Lancet, 395(I0228), pp.93I-934.

Andersen, M., 2020. Early evidence on social distancing in response to COVID-19 in the United States. Available at SSRN 3569368.

Ajzenman, N., Cavalcanti, T. and Da Mata, D., 2020. More than words: Leaders' speech and risky 
behavior during a pandemic. Available at SSRN 3582908.

Atchison, C., Bowman, L., Eaton, J., Imai, N., Redd, R., Pristera, P. and Ward, H., 2020. Report 10: Public response to UK Government recommendations on COVID-19: population survey, I7-18 March 2020.

Bargain, O. and Aminjonov, U., 2020. Trust and Compliance to Public Health Policies in Times of COVID-I9.

Bai, Y., Yao, L., Wei, T., Tian, F., Jin, D.Y., Chen, L. and Wang, M., 2020. Presumed asymptomatic carrier transmission of COVID19. Jama, 323(14), pp.|406-1407.

Briscese, G., Lacetera, N., Macis, M. and Tonin, M., 2020. Compliance with covid-19 social-distancing measures in italy: the role of expectations and duration (No. w26916). National Bureau of Economic Research.

Bikbov, B. and Bikbov, A., 2020. Communication on COVID-19 to community-measures to prevent a second wave of epidemic.

Bausch, D.G., 2020. Precision physical distancing for COVID-19: An important tool in unlocking the lockdown. The American Journal of Tropical Medicine and Hygiene, p.tpmd200359.

Brzezinski, A., Deiana, G., Kecht, V. and Van Dijcke, D., 2020. The covid-19 pandemic: government vs. community action across the united states. Covid Economics: Vetted and Real-Time Papers, 7, pp.II5-I56.

Chen, S., Yang, J., Yang, W., Wang, C. and Bärnighausen, T., 2020. COVID-19 control in China during mass population movements at New Year. The Lancet, 395(I0226), pp.764-766.

Ebrahim, S.H., Ahmed, Q.A., Gozzer, E., Schlagenhauf, P. and Memish, Z.A., 2020. Covid-19 and community mitigation strategies in a pandemic.

Ferguson, N.M., Laydon, D., Nedjati-Gilani, G., Imai, N., Ainslie, K. and Baguelin, M., 2020. Imperial College COVID-19 Response Team. Impact of non-pharmaceutical interventions (NPIs) to reduce COVID-19 mortality and healthcare demand. Published March I6, 2020.

Greer, S.L., King, E.J., da Fonseca, E.M. and PeraltaSantos, A., 2020. The comparative politics of COVID-19: The need to understand government responses. Global Public Health, P. I-4.

Hsiang, S.M. and Jina, A.S., 2014. The causal effect of environmental catastrophe on long-run economic growth: Evidence from 6,700 cyclones (No. w20352). National Bureau of Economic Research.
Hellewell, J., Abbott, S., Gimma, A., Bosse, N.I., Jarvis, C.I., Russell, T.W., Munday, J.D., Kucharski, A.J., Edmunds, W.J., Sun, F. and Flasche, S., 2020. Feasibility of controlling COVID-19 outbreaks by isolation of cases and contacts. The Lancet Global Health.

Ireton, C. and Posetti, J., 2018. Journalism, fake news \& disinformation: handbook for journalism education and training. UNESCO Publishing.

Kraemer, M.U., Yang, C.H., Gutierrez, B., Wu, C.H., Klein, B., Pigott, D.M., Du Plessis, L., Faria, N.R., Li, R., Hanage, W.P. and Brownstein, J.S., 2020. The effect of human mobility and control measures on the COVID-19 epidemic in China. Science, 368(6490), pp.493-497.

Kissler, S.M., Tedijanto, C., Goldstein, E., Grad, Y.H. and Lipsitch, M., 2020. Projecting the transmission dynamics of SARS-CoV-2 through the postpandemic period. Science, 368(6493), pp.860-868.

Lipsitch, M., Swerdlow, D.L. and Finelli, L., 2020. Defining the epidemiology of Covid-19studies needed. New England journal of medicine, 382( I3), Pp. I I94-I I 96.

Martin, R.A. and Ford, T., 2018. The psychology of humor: An integrative approach. Academic press.

Mariani, L., Gagete-Miranda, J. and Retti, P., 2020. Words can hurt: How political communication can change the pace of an epidemic. DOl: https://doi. org//0.3/235/osf. io/a32r7.

Rothgerber, H., Wilson, T., Whaley, D., Rosenfeld, D.L., Humphrey, M., Moore, A. and Bihl, A., 2020. Politicizing the covid-19 pandemic: Ideological differences in adherence to social distancing.

Seres, G., Balleyer, A., Cerutti, N., Danilov, A., Friedrichsen, J., Liu, Y. and Süer, M., 2020. Face Masks Increase Compliance with Physical distancing Recommendations During the COVID-19 Pandemic. argument, 20, p.44.

Tanne, J.H., Hayasaki, E., Zastrow, M., Pulla, P., Smith, P. and Rada, A.G., 2020. Covid-19: how doctors and healthcare systems are tackling coronavirus worldwide. Bmj, 368

Viner, R.M., Russell, S.J., Croker, H., Packer, J., Ward, J., Stansfield, C., Mytton, O., Bonell, C. and Booy, R., 2020. School closure and management practices during coronavirus outbreaks including COVID-19: a rapid systematic review. The Lancet Child \& Adolescent Health.

Wilder-Smith, A. and Freedman, D.O., 2020. Isolation, quarantine, social distancing and community containment: pivotal role for oldstyle public health measures in the novel 
coronavirus (2019-nCoV) outbreak. Journal of travel medicine, 27(2), p.taaa020.

Wu, Z. and McGoogan, J.M., 2020. Characteristics of and important lessons from the coronavirus disease 2019 (COVID-19) outbreak in China: summary of a report of 72314 cases from the Chinese Center for Disease Control and Prevention. Jama, 323(I3), pp. I239-I 242.

World Health Organization, 2020. Coronavirus disease 2019 (COVID-19): situation report, 72. 